\title{
Address delivered at the Annual Meeting of the Fund
}

\section{W. Wilson}

To cite this article: C. W. Wilson (1899) Address delivered at the Annual Meeting of the Fund, Palestine Exploration Quarterly, 31:4, 304-316, DOI: 10.1179/peq.1899.31.4.304

To link to this article: http://dx.doi.org/10.1179/peq.1899.31.4.304

曲 Published online: 20 Nov 2013.

Submit your article to this journal $\pi$

Џ Article views: 4

Q View related articles $\longleftarrow$ 


\section{ADDRESS DELIVERED AT THE ANNUAL MEETING OF THE FUNI).}

By Major-General Sir C. W. WrLson, K.C.B., F.R.S., \&c.

Lord Amherst, ladies, and gentlemen, before giving you a brief account of my visit to Moab, I wish to make a few remarks on some points that came under my notice in other parts of Palestine.

I visited the excavations that were being made for the Fund at Tell Zakarîya, and can endorse what Mr. Morrison has said with regard to Dr. Bliss and Mr. Macalister. They are both good men, and take great interest in their work. The ruins on Tell Zakarîya are those of a small town and acropolis which have been rebuilt three or four times; and in my opinion the last reconstruction took place during the time of the Maccabees. One very interesting feature, which probably dates from the earliest settlement on the Tell, is the number of rock-hewn chambers that communicate with each other. These almost certainly formed a place of refuge for the inhabitants in the case of hostile raids which could not be met in the field. The excavations which are carried out by the Fund are of great importance, for Palestine is changing more rapidly than anyone who has not been there in recent years can possibly imagine.

I am sorry to say that the native tomb-hunter, who has done and is still doing irreparable mischief in Egypt, is now at work in Palestine. At Susiyeh, the ancient Hippos, exst of the Sea of Galilee, a large number of gold ornaments, terra-cotta vessels, and other objects of art have been taken by the fellahîn from tombs which they have broken into and rifled. The inds are sold secretly in different parts of the country, from fear of the local authorities, and they pass into private collections where it is impossible to trace them. Many of the articles that have thus been dispersed are probably of great archæological interest and value, for Hippos was settled by Macedonians after the conquest of Syria by Alexander.

One great change in Palestine is due to what I might almost call a mediæval revival. During the last 20 years there has been 
a remarkable scramble for "holy places," and this has resulted in the erection of numerous churches and monasteries throughout the country. There is now hardly any "site" in Palestine that is not occupied by a monastery or a church. Most of these buildings are in the very worst taste, and in the erection of some of them much damage has been done to the remains of more ancient structures. At Jerusalem, for instance, the Greeks, whilst excavating in the Muristân to the south of the Church of the Holy Sepuichre, uncovered the foundations of the Church of St. Mary the Less, which was built by the Latins in the twelfth century. These, I regret to say, were wantonily destroyed, and several capitals from Constantine's basilica which had been re-used by the builders of the church, shared the same fate. On the site of the church was found a valuable reliquary, displaying great artistic taste, which is now preserved in the Greek Treasury in the Church of the Holy Sepulchre. The reliquary is of interest to Englishmen, for a relic of Oswald, the Anglo-Saxon King of Northumbria in the seventh century, occupies the place of honour amongst small fragments of the true cross and other relics. It must have been buried or hastily concealed, when the city was taken by Saladin, by someone who lost his life at that time.

At Tell Hûm, which many authorities believe to be the site of Capernaum, the synagogue that I partially excavated in 1866 . has been much damaged. The Franciscans, who have built a small hospice, or monastery, amidst the ruins of the town, have included the building within the walls of their garden, and have planted mulberry trees over it.

At Medeba, east of Jordan, the Greeks have partly destroyed a large map of Palestine, Egypt, Sinai, and Mesopotamia, in mosaic, which was probably made in the early part of the fifth century. Some of the most interesting portions of the map have been completely destroyed, but even in its fragmentary state it is one of the most valuable geographical discoveries of recent years in Palestine.

Perhaps the greatest change is that which has been made in the aspect of several districts by the labours of the Jewish colonists. I must confess that I was quite unprepared for the excellent results that have been already obtained by the colonists. They have turned land which I remember as waste, and almost 
desert, into smiling gardens, orchards, and vineyards, or covered it with heavy crops of wheat and barley. In 1882, when I rode from the Sea of Galilee to the waters of Merom there was scarcely a trace of cultivation in the Jordan Valley. This year I found the valley, where not planted with almond and olive trees; a waving mass of corn. At Ekron, a colony which every traveller in Palestine should visit, there are large plantations of olive, almond, pomegranate, and other fruit trees. Nowhere can be seen more clearly what the country might become under a proper system of cultivation, and what it probably was before the Arab conquest. It has been stated that Jews do not take kindly to agriculture. The question seems to be one of training, and much has been done in this direction by the Agricultural School of the Alliance Israèlite at Jaffa, and by Baron Edmond de Rothschild, who has had several of the most promising young Jews educated at the best agricultural schools in France. In some places I saw Jewish colonists working in the fields as if their hearts were really in the work. The results obtained by the colonists have had a marked influence on the native tillers of the soil, who, whether Christian or Moslem, are gradually adopting more scientific methods of cultivation in their fields and vineyards.

I may here allude to an interesting struggle that is going on between the Russiar and the Orthodox Greek Churches. The Russians have opened a large number of schools in Palestine, in which Russian is taught, and their ostensible object is to create a national Arab Church, on the lines of the Bülgarian Church. "This policy is opposed in every possible way by the Greek Orthodox Church, which relies on the support of the Turkish Government. This year the Greeks, to show their loyalty to the Sultan, and possibly to annoy the Russians, hoisted the Turkish flag on the tower of the Church of the Holy Sepulchre during the Easter ceremonies, at which a Russian Admiral and a detachment of his sailors were present. It is, I believe, the first occasion upon which a Turkish flag has been hoisted on a Christian Church, and as it marks a new departure, a photograph of the church with the flag flying may be of interest.

My visit to Moab and Edom was very hurried, but it enabled me to examine the broad geographical features of the country, and to realise their influence on its history. I was fortunate in having as my companion Mr. C. Hornstein, the head master of 
the Christ Church School for Jewish boys at Jerusalem, ${ }^{1}$ who had previously visited Kerak and Petra, and was received by everyone as an old friend. His knowledge of the people and their language smoothed all difficulties, and to his skill as a phctographer we are indebted for the beautiful photographs that will be shown on the screen.

Moab and Edom, roughly speaking, form part of a high-lying plateau, which on the west breaks down to the Dead Sea and the -Arabah in a succession of abrupt cliffs and terraces, and on the east slopes gradually downwards until it merges in the great expanse of the Syrian Desert. From Jebel Neba (2,643 feet), on the north, there is a steady rise to the downs above Petra $(5,320$ feet $)$, on the south.

The district owes much of its characteristic scenery to the fracture of the earth's crust which formed the Jordan Valley, and the great depression that extends southwards to the Red Sea. The effect of this fracture has been to displace the strata vertically, so that those on the eastern side of the deep, trough-like valley have been relatively elevated. At the base of the eastern escarpment, near Petra, red sandstone and conglomerate, capped by fossiliferous limestone of the carboniferous period, rest on a foundation of old crystalline rocks. 'The limestone is succeeded by a soft cretaceous sandstone, of variegated coluurs, that represents the Nubian sandstone, and this is surmounted by a cretaceous limestone with thick beds of flint, which underlies the surface soil of the plateau, and corresponds to the chalk formation of the British Isles. In certain localities-as, for instance, east of Jebel Shihân, and east of $W \hat{a} d y$ Shobek-the limestone passes under sheets of basaltic lava. North of Petra the older rocks gradually disappear, but along the east shore of the Dead Sea the Nubian sandstone is always visible, and is deeply cut into by the lateral valleys, which are really fractures branching off from the main fracture already mentioned.

The general aspect of the limestone plateau is not unlike that of the Sussex Downs or the Yorkshire Wolds. The platean affords excellent pasture and, where cultivated, yields good crops of barley. There are a few scattered trees, and at one spot,

I I have to thank the Rev. A. H. Kelk, Incumbent of Christ Church, and the Committee of the London Society for Promoting Christianity amongst the Jews, for kindly granting Mr. Hornstein permission to accompany me. 
between Shobek and Petra, there is an oak wood of some size. In the Bible these downs are called the Mishor (A.V., "plain country") of Edom and Moab. The basalt districts, with their rich, productive soil, are the Sadeh (A.V., "field") of the two countries. The lower desert region to the east is the Midbar (A.V., "wilderness"); to the north, after the rains, it affords sufficient vegetation for the camels, sheep, and goats of the Bedawin; but southwards, in the vicinity of M'aân, the level surface is covered with loose black flints, and the desert assumes a most forbidding aspect. The soft Nubian sandstone, which weathers into quaint, picturesque forms, offers great facilities for excavation, and in it are hewn the temples, dwelling-places, and tombs of Petra, el-Barid, and el-Beidha.

The valleys which drain the platean are at first broad and open, but they afterwards suddenly break down into wild, rocky ravines, and, where they pass out through rifts in the escarpment to the Dead Sea and the 'Arabah, they become deep chasms. These ravines, which are only passable at certain points, have in all ages greatly influenced the direction of the lines of communication. In most of them there are perennial streams of water fringed with oleanders and fairly stocked with fish. In the deep rifts, where the ruddy-coloured sandstone is exposed, the rock scenery is wild and grand. The three most important valleys which, with their tributaries, drain by far the larger portion of the plateau, are: Wâdy el-Mojib (the Arnon), which formed a natural boundary between Israel and Moab; Wâdy el-Ahsi or Hesi (the brook Zered), which separated Moab from Edom; and Wâdy el-Ithm, which parted Edom from Midian. Other deeplycut valleys are Wâdy Zerka Mấân, in which lie the hot sulphur springs of Callirrhoe, Wâdy Kerak, Wâdy Tufileh, Wâdy Shobek, and $W \hat{a} d y$ Mus $\hat{a}$, through which ran the Roman road viâ Petra to the Gulf of 'Akabah.

Edom is divided into two separate districts by a remarkable break in the hills that form the western edge of the plateau, and not by a valley. This break, from its proximity to Shobek, I venture to call the "Sbobek Gap." The northern district, Jebeil, is the Gebal of Psalm lxxxiii, 7, which at a later pericd gave its name, Gobolitis, or Gebalene, to the whole country. The southern is Sherah, or Edom proper. Another interesting feature in Edom is the separation of the bare sandstone ridge, of which Mount Hor 
is the eulminating point, from the massif of the plateau. This is clearly seen when looking down upon Mount Hor from the edge of the plateau above Petra. To this ridge the name Mount Seir seems specially applicable.

There are no springs except in the valleys. The inhabitants of the towns on the plateau depended for their water supply upon the rainfall, which was collected in rock-hewn cisterns and open reservoirs: In several localities the soil is good and well adapted to the growth of cereals, but the population is so sparse that only :a small proportion of the available land has been cultivated. Wherever there is water, as at Kerak, Tufîleh, Elji, and M'aân, the olive, fig, pomegranate, and vine thrive well, and at Elji the poplar is grown for its wood. The traces of ancient cultivation are very apparent in the dams and retaining walls which were ibuilt across the valleys to keep the soil from being washed away by the winter rains. The climate is colder than that of Western Palestine; snowstorms are not uncommon in winter and spring, and at those seasons the easterly winds are extremely cold. Whilst we were suffering from cold the easterly winds, driving the heated air of the Jordan valley westward, produced great heat and a sirocco wind at Jerusalem. The summer is hot, but on the platean the nights are always cool. In Moab there appears to ibe a fair rainfall, but in the southern portions of Edom there is little rain.

There are numerous remains of the ancient roads, and the great Roman road which ran from Medeba to the Gulf of 'Akabah can be traced as far as Petra. Many of the milestones, with much-worn inscriptions, remain where they have fallen, and in places the roadway is still quite perfect. In the Wâdy Mojib, where the descent on the north side is 1,860 feet and the ascent on the south side 2,040 feet, and also in Wâdy el-Hesi, where the descent and ascent are respectively 2,450 feet and 2,800 feet, the gradients were laid out with great skill. Unfortunately the old roadway has long been destroyed, and there is now only a track for pack animals. Another main road followed nearly the line .of the present Haj road, which runs near the edge of the desert and does not cross any deep ravine. These two lines of communication were connected by minor branch roads. During the Roman period the roads were protected by guard houses, or small military posts; and the whole country was protected from 
the incursions of the nomads by a chain of forts that ran from north to south, and were apparently garrisoned by the legion which seems to have been quartered at Lejjûn. From an inscription on one of the forts, Kasr Bishîr, it would appear that the line of fortifications was strengthened and restored in the early part of the fourth century.

The large number of ruins show that the country at one time had a large settled population. Most of them, it is true, mark the. sites of villages or small towns; but some, as for instance those at er-Rabba, Datras, and Umm er-Rasas, are the remains of important cities. Very few of the ancient sites have been occupied since the Arab conquest, and they consequently offer a favourable field for exploration. This is specially the case with $e r-R a b b a$ (Ar of Míoab), where excavations would lead to important discoveries.

I obtained some new Greek inscriptions at Kerak, and possibly a few new Nabathean inscriptions from Petra and its vicinity. Many others, perhaps Moabite, and certainly Nabathean and Greek, would be found by excavation. I heard of several inscriptions that had been buried by their finders, but was unable to see them. The Turkish occupation has made excavation easy and possible; but it has also, by giving protection from the nomads, encouraged the reoccupation of deserted sites, and so opened the way to the destruction of ancient remains. It is, therefore, most important that excavations should be carried out at an early date. The destruction of a great part of the Medeba mosaic is a warning that should not be neglected.

It may be of interest to mention here that the route of the Israelites from the Gulf of 'Akabah to the Jordan lies within very narrow limits. After ascending Wâdy Ithm, they must have camped near $M^{6} a \hat{a} n$, where there is an abundant supply of water. They then probably followed the Haj road to the stream in $W a \hat{d} y$ el-Hesi, and after crossing the upper part of the Seil es$S^{\prime}$ aideh turned west by Umm er-Rasas to Dhibân. From this last place northward to Mount Nebo the road is easy and well defined.

We crossed the Jordan by a bridge on or near the site of the flying bridge represented on the Medeba mosaic, and, after making. our way across the "plains of Moab," commenced the ascent of the hills on the east. For some distance we followed the Roman road by the side of which are several fallen milestones, and then turned off to pass the night at a Bedawi camp on the slopes of 
Pisgah, above the springs ('Ayîn Mîsâ) which are generally identified with Ashdoth Pisgah. Next morning we ascended Pisgah (Râs Sîâghah), but heavy clouds covered the western hills and we saw little of the extensive view which the hill commands.

From Pisgah we rode over rich arable land to $M \hat{a}^{6} a \hat{\imath} n$ (Bethbaal-meon), where we found the ruins occupied by Christians from Kerak, who had repaired some of the old houses. They had uncovered nothing of importance, but it is a place where discoveries may be expected, and it should be occasionally visited. We next descended to the hot sulphur springs in the gorge of the Wâdy Zerka Mấ $a \hat{\imath} n$ (Callirrhoe), which were visited by Herod the Great. The absence of any remains of importance possibly indicates that visitors encamped when going through a course of baths. A steep climb of about 2,800 feet took us to $M^{\prime}$ akaur (Machaerus); and thence we rode by Khurbet Attarûs, and Jebel Attarîs to the Roman road which we struck a little to the south of Libb and followed to the Wâdy Wâleh and the Mojib. Before reaching the Wâleh we passed a Roman post with a group of milestones, and a similar group was noticed shortly before we reached the stream of the Mojib. At the Mojib we found that the road on both banks had been greatly improved by the Turkish soldiers, and that the passage of the great rift was now comparatively easy.

Leaving the south side of the rift, where there is now a Turkish guard-house, we soon entered the rich basaltic plain that stretches. southward past Rabba (Ar of Moab) to the vicinity of Kerak. At this last place we were hospitably received by the Turkish officers, and by the Greek Archimandrite, in whose house we lodged. Every facility was given for visiting the castle and all parts of the town, and an examination of them seemed to show that though in many places the lower portions of the walls and towers may be Roman, or even earlier, the castle and the town walls are, as a whole, the work of the Crusaders and an extremely fine example of mediæval fortification. With the exception of necessary repairs, few additions have been made to the works since the place was held against the might of Saladin by that audacious freebooter Renaud de Chatillon, who was slain after the disastrous battle of Hattin. The inscriptions of Bibars were manifestly irserted in towers which he repaired but did not build. It is not easy to determine the limit of the pre-Roman city and fortress, but it was probably conterminous with that of the 
present town. The four rock-hewn tunnels which were formerly the only entrances to the town appear to be very ancient and to have belonged to the old Moabite city. In one of them we came across an instance of the careless disposal of the dead in the bodies of a number of children that had been simply wrapped in a cloth and laid upon the ledges of rock. There are a few Roman remains and Greek inscriptions in the town, and I was able to copy some new inscriptions that had been found in a tomb by the Rev. Mr. Forder. Amongst the people of Kerak the Christians, who, like the Moslems, take to their tents in the summer, are of special interest.

Travelling south from Kerak we came to the spot where Jaafar et-Taiyar, Muharmmad's cousin; Zeid, his adopted son; and Abdullah ibn Rawâha, the poet, who were killed at the battle of Moteh, lie buried. The battle, of which a picturesque description has come down to us, was the first in which the followers of Muhammad met a Roman army. They were sharply defeated with the loss of their three leaders, and were only saved from complete destruction by the genius of Khalid, who was soon to be the conqueror of Syria. Some doubt had been expressed as to the truth of the tradition that Jaafar was buried at this place, and excavations were made under a young Turkish officer. An inscription in Kufic was found which left no doubt as to the accuracy of the tradition. The Arabs assembled at M'aân and, marching by the Roman road through Datras, met the Imperial army on the plain between Jaafar and Kerak. The scene that followed can be realised from the descriptions of the battle of Omdurman, where the Baggara charged and fought with all the impetuosity of their Arab ancestors. Jaafar led the final charge, banner in hand, and as he rushed forward to perish in the ranks of the Christians he chanted the following words:- " Paradise! How fair a resting place. Cold is the water there, and sweet the shade! Rome! Rome! thine hour of tribulation draweth nigh. When I close with her, I will strike her down to the ground."

Leaving Jaafar we crossed the deep Wâdy el-Hesi, and, entering the district of Jebeil (Gebal), visited Tufilleh (Tophel). The place is still inhabited, and is noted for the number of its springs, and for its olive groves, its fig trees, and its productive gardens. From the top of the little castle that crowns the hill there is a riew of exceptional beauty and interest over the Dead Sea. From Tufilleh our route led past Buseira (Bozrah) and Gharandel (Arindela) to 
a break in the hills that separates Gebal from Edom proper, and to a basaltic plain which answers well to the "field" (sadeh) of Edom. From the plain we descended sharply to the bed of Wâdy Shobek, and followed it up to the base of the hill upon which stands Shobek, the Mons Regalis of the Crusaders. The castle was built by Baldwin $I$ in a position of great natural strength within easy reach of the great caravan road from Cairo to Damascus. It thus commanded the principal line of communication between the capitals of Egypt and Syria, and several fruitless attempts to take it were made by Saladin. The fortress, before the introduction of fire-arms, must have been impregnable, and it only fell when the garrison were nearly starved and there was no hope of relief. The walls are very fine, and there are remains of the Church of the Crusaders and other buildings. The most curious feature is a deep well with, so it is said, 375 steps to the water. There are several springs from which water is led away to irrigate a number of terraced gardens. Nothing older than the period of the Crusades was seen, but the site is such an important one that it must always have been occupied, and was probably the home of one of the Dukes of Edom.

Soon after re-crossing $W a \hat{d} d y$ Shobel, on our way southward, we again struck the Roman road near 'Ain Nejel, a fine spring which retains the name of Negla, a station mentioned in the "Itinerary" of the road to Petra. The ruins near the spring are probably those of Negla. We left the Roman road before it entered $W \hat{a} d y$ Misa, and, turning to the right, rode through a large wood of oaks to the edge of the platean above the "Arabah. The view from this point was most extensive and interesting. Petra lay almost at our feet. Mount Hor was several hundred feet below us, and the detached ridge of which it forms part could be traced far to the north and south. Beyond Mount Hor lay the "Arabah, and in the far distance the wide expanse of the desert of the Tîh.

We entered Petra by the Sik, and lived in the Khazneh whilst visiting the rock-hewn monuments which have been so often described. We were able to ascend Mount Hor, and make a careful examination and take photographs of the interior of Aaron's tomb. The present structure has evidently taken the place of a Byzantine shrine, for we found one stone with a cross upon it, and another with a mutilated Greek inscription. On leaving Petra we paid a short visit to el-Beidha and el-Barid, where the rock excavations, 
though on a smaller scale, are almost as interesting as those of Petra. The style of the monuments is not so florid, and to this they probably owe their better preservation. There is no water in this section of the sandstone ridge, and elaborate arrangements were made to collect the rainfall and conduct it into rock-hewn cisterns. We copied a few Nabathean inscriptions, but were not abie to give the place the careful examination that it requires. The whole sandstone ridge appears to be full of rock-hewn tombs and dwelling-places, and any traveller who could devote a few weeks to its exploration would reap a rich harvest of inscriptions.

Our route from el-Barid lay through the large village of Elji and its well-watered gardens, and up a narrow valley to the western edge of the plateau. Thence we descended to $M^{\prime} a \hat{a} n$, which lies well out on the flint desert, and is one of the principal stations on the Haj road from Damascus to Mecca. There are two M'aâns : the larger, $M^{\prime} a \hat{a} n$ Kibleh, lies to the south, and is

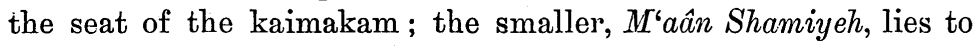
the north. Both have an abundance of water, from springs and small streams that have their sources some distance to the west, and serve to irrigate extensive gardens. The Serai is in a castle which, according to an inscription, was built by Sultan Selim I, who paid much attention to the stations on the Haj road. Here and there in the village there are capitals and worked stones, which show that the place was occupied during the Roman period. About a mile from $M^{\prime}$ aân there is a large reservoir, which was formerly supplied by an aqueduct from the stream at $M^{\prime} a \hat{a} n$ Shamiyeh. This tank and the ruins near it probably date from the time of the Damascus khalifs, ${ }^{1}$ who carried out extensive works for the convenience of the Haj. At present the pilgrims camp on the desert between the two M'aâns, and obtain their water from the streams. $M^{\prime} a \hat{a} n$, which is three days' journey from the Gulf of 'Akabah, must have been one of the stations of the Israelites on their way to the Holy Land. It is possibly the place from which the Maonites, Mehunim, or Meunim took their name, or it may have taken its name from them.

From M'aân we rode across the flint desert to Kalah Aneyzeh, where there are a small castle and a reservoir, both in bad repair,

1 I could find nothing distinctively Roman, and it seems improbable that the Romans would have constructed works of this kind for a military station near an abundant supply of water. The ruins have nothing in common with those of the military stations at Lejjîn and Odruh. 
and the next day to Kalah el-Ahsi, where we turned to the left to camp by a stream, "the brook Zered," in the Wâdy el-Ahsi. Here we were obliged to return to Kerak to have the animals reshod-a change in the programme which took us through Datras, where there are the ruins of two temples and of a large town. Datras is apparently the Thorma of the "Itinerary," a place otherwise little known to us, though it must have been an important town and occupied a commanding position near the northern edge of Wâdy el-Ahsi. The water supply, as in nearly all the towns on the plateau, was derived from the rainfall stored in rock-hewn cisterns.

Leaving Kerak we rode out by the ruins of Chinar, and $A d r$ or Adar, to Lejjûn, a Roman fortified camp which was planned by Dr. Bliss and described by him in the Quarterly Statement for July, 1895. The camp is well situated in open ground in Wâdy Lejjîn, near the source of one of the principal feeders of the Arnon. From its name it was probably the headquarters of the Legion that garrisoned the line of posts along the desert frontier of Moab and Edom. On a spur of the hills above the camp are the ruins of a building on a raised platform, which one of the Bedawîn tribes uses as a place of burial. The tribe apparently has little regard for the dead, since the bodies of men and women are laid on the ruins in the flowing white or blue garments they wore in life and left to the tender mercies of dogs and hyenas.

About two and a quarter hours after crossing Wâdy Lejjûn we passed several rectangular stone struetures called Rijum Rishan. These buildings, which are common on the downs, are usually situated on the top of hills and ridges. They have two chambers covered with stone slabs, and are apparently tombs similar to those in the Wâdy Feirân in Sinai. Later we crossed Wâdy el-Midhad, and then rode over the downs to a camp of Salaita Bedawîn, where we passed the night. Next day we visited Kasr Bishir, of which Dr. Bliss has also given a plan, and then rode to the extensive ruins of Umm er-Rasas. Here I was able to examine the construction of the stone houses and cisterns which are roofed with large flat slabs resting on parallel rows of closely spaced arches built without mortar. Within the fortified enclosure I noticed the remains of two churches, and on the outside there were the ruins of some large buildings. Great care was taken to retain the soil in the shallow valleys and on the slopes of the hills near the town by massive walls, and to collect the 
rainfall in numerous well-constructed cisterns. About a mile from the ruins is the curious tower which has been the subject of much speculation. It apparently stood in the open court of a small monastery, of which there are considerable remains, and was perhaps a Stylite tower. Its position, much lower than that of the town, does not favour the view that it was a watch tower. A rude flight of steps, now blocked by fallen stones, winds round the: inside. If $U \mathrm{~mm}$ er-Rasas be, as has been suggested, the archiepiscopal city of Mépw or Mépov, then the tower is probably that of Sylitus. From the tower we rode over the downs to. Wâdy Themed, and thence by the interesting ruius of Nittle, a town with stone houses similar to those at Umm er-Rasas, to Medeba.

At Medeba I examined the mosaic map which, when perfect, included Egypt, Sinai, Palestine, Syria, and part of Mesopotamia. It is, in its mutilated state, an interesting illustration of the condition of the country before the Arab conquest, and of the views that then prevailed with regard to sites of Biblical interest. The colours in the mosaic, when wetted, are still quite fresh, and in the plan of Jerusalem I was able to see several details that I had not noticed on any copy. There is, unfortunately, no facsimile of the mosaic in colour. Such a copy is much to be desired, for the colours, especially in the large towns, appear to be used conventionally and in accordance with fixed rules. There is a low railing round the mosaic, but it does not completely protect it, and it is desirable that a coloured facsimile should be made at an early date. There are several other fine mosaics at Medeba, of which one is dated; but the era from which the date is counted is at present unknown. From Medeba we returned by Jericho to Jerusalem.

Moab and Edom, though not strictly forming part of the Holy Land, are so closely connected with it that they should be surveyed and examined with the same accuracy as Western Palestine, and excavations should be made before ruins and inscriptions have been destroyed by squatters. The topographical features are interesting; there is much of importance to the geologist; and the discovery of inscriptions like that of King Mesha on the "Moabite stone," is not only possible but probable. The occupation of the country by the Turks has facilitated exploration, and the sooner it is undertaken the greater will be the results. 